JPE (Jurnal Pendidikan Edutama) Vol. 6 No. 1 Januari 2019

P-ISSN : 2339-2258 (Print) E-ISSN: 2548-821X (Online)

http://ejurnal.ikippgribojonegoro.ac.id/index.php/JPE

\title{
PENGEMBANGAN SUMBER BELAJAR BERMAIN BERBASIS MOBILE LEARNING
}

\author{
Yenti Juniarti $^{1)}$ Eva Gustiana ${ }^{2)}$ \\ ${ }^{1,2}$ Pendidikan Guru Pendidikan Anak Usia Dini, STKIP Muhammadiyah Kuningan \\ email: yenti_juniarti@upmk.ac.id \\ email: eva_psikologi@upmk.ac.id
}

\begin{abstract}
This research aims to develop learning resources for playing subjects. The development of learning resources produces products in the form of play applications that are packaged in the form of $*$ apk that can be installed in mobile phone an-based Android. The research method used is research and development methods with development steps designed by Dick \& Carry. The subjects of this study were students of early childhood education who had 35 subjects. Based on data analysis needs obtained $100 \%$ results of students need the development of this learning resource. Whereas according to the results of expert play evaluation obtained an average score of 3.58 (very good) with a percentage of $89.44 \%$, according to learning technology experts obtained an average score of 3.56 (very good) with a percentage of $89.34 \%$, learning experts obtained an average score of 3.67 (very good) with a percentage of $91.67 \%$. The trial results of small groups obtained an average score of 3.26 (good) with a percentage of $80.09 \%$, while the results of the large group trial obtained an average score of 3.57 (very good) with a percentage of $87.96 \%$.
\end{abstract}

Keywords: Learning Resources, Playing, Mobile Learning

\begin{abstract}
Abstrak: Penelitian ini bertujuan untuk mengembangkan sumber belajar matakuliah bermain. Pengembangan sumber belajar ini menghasilkan produk berupa aplikasi bermain yang dikemas dalam bentuk *apk yang bisa di install dalam handphone berbasis android. Metode penelitian yang digunakan adalah metode penelitian dan pengembangan dengan langkah-langkah pengembangan yang dirancang oleh Dick \& Carry. Subjek dari penelitian ini adalah mahasiswa Pendidikan anak usia dini yang telah memperoleh mata kuliah bermain sebanyak 35 mahasiswa. Berdasarkan data analisis kebutuhan diperoleh hasil 100\% mahasiswa membutuhkan pengembangan sumber belajar ini. Sedangkan menurut hasil evaluasi ahli bermain diperoleh rata-rata skor sebesar 3,58 (sangat baik) dengan persentase sebesar 89,44\%, menurut ahli teknologi pembelajaran diperoleh rata-rata skor sebesar 3,56 (sangat baik) dengan persentase sebesar $89,34 \%$, ahli pembelajaran diperoleh rata-rata skor sebesar 3,67 (sangat baik) dengan persentasenya 91,67\%. Hasil uji coba kelompok kecil memperoleh rata-rata skor 3,26 (baik) dengan persentase 80,09\%, sedangkan hasil uji coba kelompok besar diperoleh rata-rata skor sebesar 3,57 (sangat baik) dengan persentase 87,96\%.
\end{abstract}

Kata kunci: Sumber Belajar, Bermain, Mobile Learning

\section{PENDAHULUAN}

Pendidikan merupakan suatu sistem yang memiliki peranan sentral dalam menentukan nasib suatu bangsa. Melalui

pendidikan masyarakat dibekali dengan 
berbagai kompetensi untuk menghadapi tantangan dunia yang semakin mengglobal. Di dalam lembaga pendidikan selalu didapatkan adanya kegiatan belajar dan pembelajaran, yaitu peserta didik belajar dan guru melaksanakan pembelajaran. Menurut Dwiyogo (2008: 2) dalam pembelajaran konvensional, pelaksanaan pembelajaran melibatkan tiga komponen utama, yaitu: dosen, mahasiswa, dan bahan. Isi yang dipelajari mahasiswa semuanya telah termuat di dalam bahan. Tugas dosen adalah memasukkan isi atau bahan kepada mahasiswa. Untuk mengetahui apakah mahasiswa telah memahami apa yang telah diajarkan dan yang akan diajarkan, mahasiswa mengerjakan tugas terstruktur yang diberikan oleh dosen.

Pembelajaran yang dilaksanakan di lembaga pendidikan tinggi tentu memiliki nuansa yang berbeda dengan lembaga pendidikan dasar dan sekolah menengah. Nuansa interaksi yang lebih dinamis antara dosen dengan mahasiswa, mahasiswa dengan sumber belajar dan bahkan dosen dengan sumber belajar itu sendiri. Proses pendidikan yang dinamis, bervariasi dengan keanekaragaman sumber belajar, media, dan model pembelajaran akan mengoptimalkan proses transfer pengetahuan antara peserta didik dengan lingkungan.

Pendidikian yang dilaksanakan di sekolah dan perguruan tinggi seiring dengan berjalannya waktu, terus mengalami perubahan. Kemajuan teknologi informasi dan komunikasi (TIK) menjadi salah satu faktor perubahan dalam sistem pendidikan di Indonesia. Teknologi mempunyai peran yang sangat penting bagi proses pendidikan serta ikut memberikan arah dalam perkembangan dunia pendidikan. Dalam sejarah perkembangan pendidikan, teknologi informasi adalah bagian dari media yang digunakan untuk menyampaikan pesan ilmu pada orang banyak, mulai dari teknologi percetakan beberapa abad yang lalu, seperti buku yang dicetak, hingga media telekomunikasi seperti, suara yang direkam pada kaset, video, televisi, $\mathrm{CD}$ dan pembelajaran melalui internet (e-learning) Arsyad (2013: 22).

Dengan adanya perkembangan teknologi, informasi visual maupun non visual informasi pembelajaran dapat disimulasikan dengan lebih nyata dan mudah ke dalam memori si pebelajar dengan berbagai cara. Mobile learning merupakan salah satu sarana yang tepat untuk memperoleh sumber belajar, dirasakan dengan kemajuan teknologi saat ini, dengan aplikasi mobile learning diharapkan mahasiswa dengan mudah mengakses berbagai sumber belajar.

Mobile learning (m-learning) adalah isu hangat yang berkembang dalam pengembangan bahan ajar sejak dari tahun 2000-an. Mobile learning memanfaatkan perangkat mobile seperti smartphone (termasuk golongan cell phone) dalam menunjang pembelajaran. Mempermudah akses sumber belajar serta menjadikan sumber belajar lebih menarik. Mobile learning memiliki tingkat fleksibilitas yang tinggi dalam hal kemudahan akses. Materi yang dipersiapkan pendidik untuk memfasilitasi peserta didik belajar mandiri bisa dikemas dalam bentuk teks, audio dan video dalam satu perangkat smartphone. Dengan demikian proses transfer pengetahuan melalui interaksi antara peserta didik dengan sumber belajar menjadi semakin mudah. Dailysocial (2018)

Bermain merupakan satu diantara rumpun mata kuliah yang ada di pendidikan anak usia dini. Bermain sebagai ruhnya pendidikan anak usia dini, Dunia anak adalah dunia bermain, dari mulai bangun 
tidur sampai tidur kembali yang ada dalam pikiran anak adalah bermain. Maka wajar apabila bermain merupakan salah satu prinsip dasar dalam pendidikan anak usia dini. Melalui bermain anak akan belajar berbagai hal, antara lain anak akan belajar mengenal lingkungan di sekitarnya, belajar dalam menguasai beberapa keterampilan hidup seperti keterampilan berbahasa, bersosialisasi, dan lainnya. Oleh sebab itu alangkah baiknya mahasiswa PAUD calon guru nantinya dibekali berbagai permainan, karena begitu banyak permainan yang bisa menstimulasi perkembangan anak, hanya saja kurangnya kreatifitas dari pemberian permainan tersebut.

Pada materi bermain dan perkembangan, mahasiswa akan dilatih bagaimana karakteristik bermain itu sendiri yang sesuai dengan perkembangan anak, artinya tidak serta merta hanya sekedar bermain tetapi bagaimana permainan itu bisa menstimulasi perkembangan anak, baik dibidang kognitif, bahasa, sosial dan moralnya. Mahasiswa harus tau konsep dan praktik permainan tersebut. Keterbatasan ruang dan waktu sehingga memungkinkan pencapaian matakuliah bermain pada materi bermain dan perkembangan sulit dilakukan mengingat begitu banyak praktik yang harus dilaksanakan. Sehingga pada akhirnya peneliti membuat sebuah aplikasi yang memungkinkan untuk dipelajari oleh mahasiswa yang bisa dikases melalui smartphone yaitu aplikasi mobile learning yang mengembangan sumber belajar pada konsep bermain dan perkembangan, sehingga nantinya dengan mudah mahaisiswa bisa memperoleh sumber belajar dari aplikasi tersebut Aliwear (2012)

\section{METODE PENELITIAN}

Penelitian ini menggunakan pendekatan penelitian dan pengembangan. Sedangkan model pengembangan yang digunakan adalah model pengembangan Research \& Development (R\&D) dari Dick dan Carey (2001) yang terdiri dari sepuluh langkah antara lain:

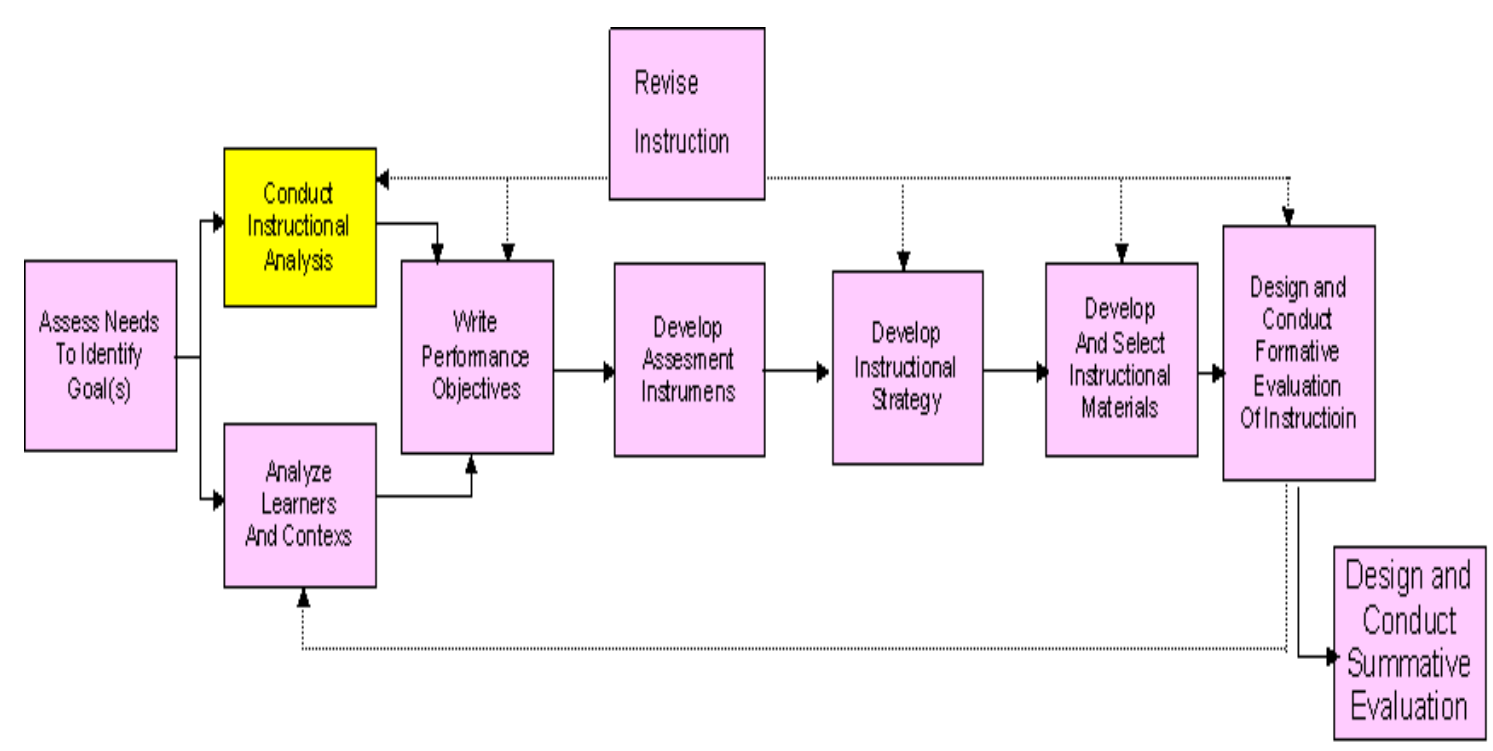

Gambar 1. Langkah Metode Research and Development (R\&D) menurut Dick dan Carey 


\section{HASIL DAN PEMBAHASAN}

Hasil analisis kebutuhan pada dapat disajikan pada tabel berikut. penelitian ini

Tabel 1. Data Hasil Analisis Kebutuhan

\begin{tabular}{|c|c|c|c|c|}
\hline NO & Item & Skor & Skor total & $\%$ \\
\hline \multirow[t]{6}{*}{1} & 1.1. Apakah anda mendapatkan matakuliah bermain? & 35 & 35 & 100 \\
\hline & \multicolumn{4}{|c|}{ 1.2. Jika ya, dalam bentuk apakah pengajaran materi matakuliah tersebut? } \\
\hline & Teori & 0 & 35 & 0 \\
\hline & Praktik & 0 & 35 & 0 \\
\hline & Teori dan Praktik & 35 & 35 & 100 \\
\hline & 1.3 apakah anda sudah menguasai materi bermain & $\mathbf{0}$ & 35 & $\mathbf{0}$ \\
\hline \multirow[t]{9}{*}{2} & $\begin{array}{l}\text { 2.1. Apakah dalam pembelajaran bermain tersebut, dosen } \\
\text { menggunakan berbagai media/sumber belajar yang } \\
\text { bervariasi? }\end{array}$ & 30 & 35 & 86 \\
\hline & \multicolumn{4}{|c|}{$\begin{array}{l}\text { 2.2. Bila menjawab Ya, apa saja bentuk sumber belajar yang tersedia? (bisa memilih lebih dari } \\
\text { satu alternatif jawaban) }\end{array}$} \\
\hline & Cetak & 35 & 35 & 100 \\
\hline & Powerpoint & 35 & 35 & 100 \\
\hline & Video & 29 & 35 & 83 \\
\hline & Internet & 35 & 35 & 100 \\
\hline & Lainnya & 0 & 35 & 0 \\
\hline & $\begin{array}{l}\text { 2.3. Apakah dosen anda pernah menggunakan sumber } \\
\text { belajar dalam bentuk mobile learning (handphone) } \\
\text { selama pembelajaran bermain? }\end{array}$ & $\mathbf{0}$ & 35 & $\mathbf{0}$ \\
\hline & $\begin{array}{l}\text { 2.4. Jika jawaban anda pernah, sebutkan dalam bentuk } \\
\text { apa? }\end{array}$ & 0 & 35 & 0 \\
\hline \multirow[t]{11}{*}{3} & $\begin{array}{l}\text { 3.1 Apakah anda memiliki Smartphone? (handphone } \\
\text { berbasis android atau iphone) }\end{array}$ & 30 & 35 & 86 \\
\hline & $\begin{array}{l}\text { 3.2. Apakah fitur-fitur dalam smartphone anda } \\
\text { memberikan kemudahan bagi anda? (secara umum) }\end{array}$ & 35 & 35 & 100 \\
\hline & \multicolumn{4}{|c|}{ 3.3. Berapa lama anda menggunakan smartphone anda dalam sehari ( 24 jam)? } \\
\hline & lebih dari 12 jam & 7 & 35 & 20 \\
\hline & kurang dari 12 jam & 27 & 35 & 77 \\
\hline & lainnya: tidak tahu & 1 & 35 & 3 \\
\hline & \multicolumn{4}{|c|}{$\begin{array}{l}\text { 3.4. aktivitas apa saja yang anda lakukan dengan smartphone anda dalam sehari? (bisa memilih } \\
\text { lebih dari satu alternatif jawaban) }\end{array}$} \\
\hline & Bersosialisasi & 35 & 35 & 100 \\
\hline & Games & 20 & 35 & 57 \\
\hline & Belajar & 17 & 35 & 49 \\
\hline & lainnya: berdagang & 1 & 35 & 3 \\
\hline 4 & $\begin{array}{l}\text { 4.1 Apakah Smartphone berpotensi untuk dijadikan } \\
\text { sumber belajar? }\end{array}$ & 35 & 35 & 100 \\
\hline
\end{tabular}




\begin{tabular}{lllll}
\hline NO & \multicolumn{1}{c}{ Item } & Skor & Skor total & $\%$ \\
\hline & $\begin{array}{l}\text { 4.2 Apakah perlu adanya pengembangan sumber } \\
\text { belajar panduan bermain dalam bentuk aplikasi } \\
\text { smartphone (mobile learning)? }\end{array}$ & 35 & 35 & 100 \\
\hline $\begin{array}{l}\text { 4.3. Akan ada pengembangan sumber belajar panduan } \\
\text { bermain dalam bentuk aplikasi smartphone, apakah } \\
\text { anda setuju dan tertarik untuk menggunakannya? }\end{array}$ & 35 & 35 & 100 \\
\hline
\end{tabular}

Hasil uji coba kelompok kecil dan belajar bermain berbasis mobile learning kelompok besar pengembangan sumber sebagai berikut:

Tabel 2. Data Hasil penelitian

\begin{tabular}{lcc}
\hline Kategori Uji Coba & Skor $\mathbf{( \% )}$ & Kreteria \\
\hline Uji Coba Kelompok Kecil & 81,09 & Valid \\
\hline Uji Coba Kelompok Besar & 87,96 & Valid \\
\hline
\end{tabular}

Berikut akan disajikan mengenai pengolahan data dari ahli bermain, ahli pembelajaran anak usia dini, ahli teknologi pembelajaran dan hasil keefektifan pengembangan sumber belajar bermain berbasis mobile learning.

\section{Analisis Data dari Ahli Teknologi Pembelajaran}

Berdasarkan hasil analisis evaluasi ahli teknologi pembelajaran diketahui bahwa jumlah skor maksimal $\left(\sum \mathrm{X}\right)$ adalah 608 dan jumlah skor yang diperoleh $\left(\sum \mathrm{X} 1\right)$ adalah 555. Sehingga, persentasenya adalah $89,34 \%$.

Berdasarkan hasil analisis yang telah dilakukan terhadap tanggapan/penilaian dari ahli teknologi pembelajaran, hasilnya adalah 89,34 \%, dari kriteria yang ditentukan dan dapat dikatakan bahwa sumber belajar bermain berbasis mobile learning ini memenuhi kriteria VALID $(\mathbf{8 0 \%}-\mathbf{1 0 0 \%})$ sehingga dapat digunakan dan dipraktekkan dalam pelaksanaan bermain.

\section{Analisis Data dari Ahli Pembelajaran Anak Usia Dini}

Berdasarkan hasil analisis evaluasi ahli pembelajaran diketahui bahwa jumlah skor maksimal $\left(\sum \mathrm{X}\right)$ adalah 48 dan jumlah skor yang diperoleh $\left(\sum \mathrm{X} 1\right)$ adalah 44 . Sehingga, persentasenya adalah $91,67 \%$.

Berdasarkan hasil analisis yang telah dilakukan terhadap tanggapan/penilaian dari ahli pembelajaran, hasilnya adalah 91,67\%, dari kriteria yang ditentukan dan dapat dikatakan bahwa sumber bermain berbasis mobile learning ini memenuhi kriteria VALID (80\% - 100\%) sehingga dapat digunakan dan dipraktekkan dalam pelaksanaan bermain.

Dalam penelitian ini telah diupayakan secara maksimal sesuai dengan kemampuan dari penulis, namun dalam penelitian masih terdapat beberapa keterbatasan yang harus diakui dan dikemukakan sebagai bahan pertimbangan dalam menggeneralisir hasil dari penelitian yang dicapai. Adapun keterbatasanketerbatasan tersebut antara lain 1) Produk aplikasi sumber belajar bermain berbasis mobile learning ini masih terbatas pada 
smartphone berbasis android dengan system operasi minimal versi 3.5 (gingerbread), 2) Produk aplikasi sumber belajar bermain berbasis mobile learning ini masih belum memiliki kemampuan menganalisis data hasil tes dan pengukuran, 3)Uji coba lapangan penelitian ini hanya dilakukan pada satu tempat, yaitu Program Studi Pendidikan Guru Pendidikan Anak Usia Dini, Sekolah Tinggi Ilmu Keguruan dan Ilmu Pendidikan dengan sampel terbatas, 4) Sumber belajar yang dikembangkan hanya terbatas pada sumber belajar materi bermain dari sekian banyak materi pada matakuliah bermain.

\section{DAFTAR RUJUKAN}

Aliwear. (2012). MOBILE LEARNING (MLEARNING) SOLUSI CERDAS PEMBELAJARAN TERKINI. Diambil dari https://alisadikinwear.wordpress.com /2012/07/07/mobile-learning-mlearning-solusi-cerdas-pembelajaranterkini/.

Arsyad, A. (2013). Media Pembelajaran. Jakarta: Rajagrafindo Persada.

Dailysocial. (2012) nelson found on smartphone utilization in asia. Diambil dari http://en.dailysocial.net/search/?q

\section{SIMPULAN}

Berdasarkan data yang diperoleh, dari hasil uji coba lapangan dan pembahasan hasil penelitian dapat disimpulkan bahwa dengan adanya sumber belajar bermain berbasis mobile learning ini mahasiswa dapat mempelajari dan melaksanakan bermain anak usia dini secara efektif dan efisien. dengan adanya sumber belajar bermainn berbasis mobile learning ini mahasiswa dapat menguasai materi teori dan praktik bermain anak usia dini dengan cepat dan benar.

\section{$=$ nielsen $\%$ E2\%80\%99s+found +0 $\underline{n+\text { smartphone+utilization+in+asia }}$}

Dick, W., Carey, L., \& Carey, J. (2001). The Systematic Design of Instruction. USA: Addison-Wesley Educational Publisher Inc.

Dwiyogo, W. D. (2008). Aplikasi Teknologi Pembelajaran Media Pembelajaran Penjas \& Olahraga. Malang: Departemen Pendidikan Nasional Universitas Negeri Malang Fakultas Ilmu Pendidikan. 